\title{
Explorations in the social history of medicine
}

Previously published at www.cmaj.ca

\author{
Essays in Honour of Michael Bliss: \\ Figuring the Social \\ E.A. Heaman, Alison Li and Shelley \\ McKellar, Editors \\ University of Toronto Press; 2007. \\ 464 pp $\$ 75.00$
}

$\mathrm{T}$ his solid collection is a testament to the fact that Michael Bliss, the distinguished Canadian historian and a professor at the University of Toronto for 38 years, is a respected colleague and a formidable mentor to his doctoral students, who are among the authors of the essays in this dedicatory anthology. Their work is complemented by the editors' introductory biography, which situates Bliss's career and scholarship by outlining his contributions as a leading popular public intellectual, the author of 10 books and a professor in the faculties of history, arts and science, with a crossappointment to medicine.

The editors deftly explore the ways in which Bliss's research career and academic mentoring guided dozens of doctoral students, who in turn, contributed significantly to shaping fields of study in Canadian social history. These students reflect a range of political and historiographical positions, whether they are reconstructing scientific accomplishments in Canadian laboratories, or questioning and challenging medical authorities through analyses of power and the impact on the vulnerable and marginalized.

Given the range of Bliss's interests, it's not surprising that the essays in this volume cover an array of subjects including Bliss's career path and influences; historical analyses of tariffs, news, religion and business; studies on fatherhood and adoption; research on the life of a Cape Breton country doctor, and social histories on endocrinology, lobotomy and care for thalidomide victims. Like Bliss's scholarship, the

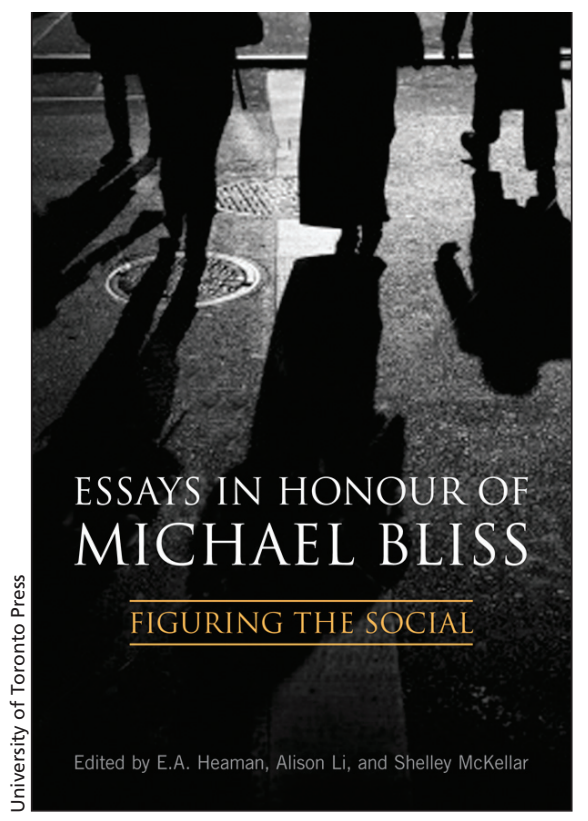

contributing authors seek to understand the broad social contexts through the lens of the individual or groups. Divergence in opinions sparked continued debate among Bliss and his students, but as E.A. Heaman describes, the common thread in their work was "the juxtaposition, contrast, and continuity between the individual and the collectivity, the self and society."

Bliss himself writes the opening autobiographical essay, where he provides insight into his scholarship and early aspiration to become a doctor like his father, who was a general practitioner and the township coroner in Kingsville, Ontario. Bliss accompanied his father on house calls, car crashes and drownings, but, by the time he was 15 , he decided to pursue studies in science at the University of Toronto. Later, he switched to philosophy: "I was interested in ... the ultimate issues about the purpose of life and the possibilities of transcendence or salvation."

About half of Bliss's books concern the history of business and politics, while the other half delves into the rich world of medical history; as he opines, "in looking at the history of medicine we are studying, revealing, and, when it is appropriate, celebrating human achievement aimed at the redemption and salvation of humankind." His books include The Discovery of Insulin (1982), Plague: A Story of Smallpox in Montreal (1991) and renowned biographies on Frederick Banting (1984), Harvey Cushing (2005) and Sir William Osler (1999). Two of these books were nominated for the Governor General's Literary Award. Through an impressive integration of archival sources, Bliss actively engages readers in the world of laboratory research, noting its complexities: "Medicine, both in theory and in practice, moves very erratically, never in a straight line."

A common theme in this volume is the impact of Bliss's high standards in academic research. As Heaman writes: "Michael Bliss has upheld standards ... of a sort that we should aspire to in expanding the range of human subjects, as so many of Bliss's students have done in their own, very diverse analyses." Bliss himself drew inspiration from Osler and other historical figures he studied: "Osler also taught us ... that the best way to handle all of the absurdities of life - medical, sacred, and secular - is to do the best we can to maintain our equanimity."

This tribute volume succeeds in providing the opportunity to learn more about the academic career of Bliss, as well as his far-reaching impact on the study of Canadian social history. The selection of excellent essays on such a wide range of timely and relevant topics is a stimulating read and opportunity for reflection, particularly for those interested in the history of medicine.

\section{Eileen O'Connor PhD}

Assistant professor

School of Human Kinetics

Faculty of Health Sciences

University of Ottawa

Ottawa, Ont. 